\title{
Cytotoxicity of alginate for orthodontic use
}

\author{
Matheus Melo Pithon', Rogério Lacerda dos Santos², Fernanda Otaviano Martins ${ }^{3}$, Maria Teresa Villela Romanos ${ }^{4}$
}

Objective: To evaluate the cytotoxicity of three different alginate impression materials for orthodontic use. Methods: Three different brands of alginate were divided into three groups, namely, Group JCO (Jeltrate Chromatic Ortho), OP (Orthoprint) and $\mathrm{CO}$ (Cavex Orthotrace). Three control groups were also included: Group C+ (positive control), consisting of detergent Tween 80; Group C- (negative control), consisting of PBS, and Group CC (cell control), consisting of cells not exposed to any material. After manipulating the materials according to the respective manufacturer instructions, samples were made with the use of silicon rings. Then the samples were immersed in Eagle's minimum essential medium (MEM) for 2 minutes. The supernatants were then removed and brought into direct contact with L929 fibroblasts. After exposure to the medium, the cells were incubated for 24 hours. Then $100 \mu \mathrm{l}$ of $0.01 \%$ neutral red dye were added. The cells were incubated again for 3 hours so that the dye could be absorbed. After this 3-hour period, the cells were fixed to perform the viable cell count, using a spectrophotometer (BioTek, Winooski, Vermont, USA) at a wavelength of $492 \mathrm{~nm}$. Results: Statistical differences were found when Groups CC and C- were compared with the other experimental groups. Group JCO had the highest cytotoxicity, followed by Groups OP and CO. Conclusion: Based on the results obtained in this work, it was concluded that all alginate impression materials are potentially cytotoxic.

Keywords: Cytotoxicity. Dental impression materials. Cell culture techniques.

Objetivo: avaliar a citotoxicidade de três diferentes alginatos de uso ortodôntico. Métodos: foram avaliados três diferentes alginatos divididos em três grupos, denominados grupo JCO (Jeltrate Chromatic Ortho), OP (Orthoprint) e CO (Carrex Orthotrace). Três grupos controle também participaram: controle $+(\mathrm{C}+)$, constituído pelo detergente celular Tween 80; controle - (C-) PBS; e controle de célula (CC) onde as células não foram expostas a nenhum material. Após manipulação dos materiais, seguindo as orientações do fabricante, foram confeccionados corpos de prova utilizando-se anéis de silicone. Em seguida, esses foram imersos em meio mínimo essencial de Eagle (MEM) por 2min, onde, então, procedeu-se à remoção do sobrenadante e à colocação em contato com fibroblastos L929. Após contato com o meio, as células foram incubadas por mais $24 \mathrm{~h}$ onde, então, foi adicionado o corante vermelho neutro a 0,01\%. Passado esse período, foram fixadas e, então, realizada contagem de células viáveis em espectrofotômetro (BioTek, Vermont, EUA) em um comprimento de onda de 492nm. Resultados: os resultados demonstraram diferenças estatística entre os grupos CC e C- com os demais. O grupo experimental JCO mostrou-se com maior citotoxicidade, seguido pelos grupso OP e CO. Conclusões: pode-se concluir, com a realização desse trabalho, que todos os alginatos testados mostraram caráter citotóxico.

Palavras-chave: Citotoxicidade celular anticorpo-dependente. Materiais para moldagem odontológica. Técnicas de cultura de células.

${ }^{1}$ Professor of Orthodontics, Southeast of Bahia State University.

${ }^{2}$ Professor of Orthodontics, Federal University of Campina Grande.

${ }^{3} \mathrm{MSc}$ in Immunobiological Technology, FIOCRUZ.

${ }^{4}$ Professor of Virology, Federal University of Rio de Janeiro.

Submitted: January 05, 2009 - Revised and accepted: August 16, 2009

\author{
How to cite this article: Pithon MM, Santos RL, Martins FO, Romanos MTV. \\ Cytotoxicity of alginate for orthodontic use. Dental Press J Orthod. 2012 Nov- \\ Dec;17(6):21.el-5. \\ » The author reports no commercial, proprietary or financial interest in the products \\ or companies described in this article. \\ Contact address: Matheus Melo Pithon \\ Av. Otávio Santos, 395 - Sala 705 - Centro \\ CEP: 45020-750 - Vitória da Conquista/BA - Brazil \\ E-mail: matheuspithon@gmail.com
}




\section{INTRODUCTION}

During the pretreatment stage, the orthodontist must collect detailed and complete documentation in order to obtain all the information required for establishing a correct diagnosis and subsequent treatment plan.,19

According to Monti $\mathrm{i}^{15}$ impression taking is the first operation to be performed when beginning orthodontic treatment, because it is important to complement diagnosis. Adequate impression taking is a fundamental requisite for fabricating orthodontic study models, from which data will be extracted that will help perform treatment. ${ }^{4,19,22}$

Alginate or irreversible hydrocolloid is the most accepted and used impression material in Orthodontics. Aiming to improve characteristics that are important to the orthodontist, the manufacturers have produced alginate powder with changes in the components. Many substances such as zinc, barium, cadmium, lead silicates and fluorides have been added to some commercial brands with the aim of improving the physical, chemical and mechanical properties, causing concern with regard to the toxicity of these materials. ${ }^{11}$

Basically, intoxication by alginate may occur by inhalation of the powder by the patient and professional, accidental ingestion by the patient and absorption by the oral mucosa in cases of repeated impression taking., ${ }^{2,3,24}$

During impression taking the alginate comes into intimate contact with the oral mucosa, which is highly vascularized and has great absorption potential, for a time interval of around 2 minutes. Therefore, the repetition of consecutive impression takings may cause a certain degree of toxicity to the patient, depending on the material composition. ${ }^{2,20}$

Based on this premise, the aim of the present article was to evaluate the cytotoxicity of three different alginate brands for orthodontic use, in a cell culture experiment.

\section{MATERIAL AND METHODS}

\section{Cell culture}

The cell lineage used was L929 (mouse fibroblast) obtained from the American Type Culture Collection (ATCC, Rockville, MD) cultivated in Eagle's minimum essential medium (MEM) (Cultilab, Campinas, São Paulo, Brazil) supplemented with $2 \mathrm{~mm}$ of
L-glutamin (Sigma, St. Louis, Missouri, USA), $50 \mu \mathrm{g} /$ $\mathrm{ml}$ of gentamicin (Schering Plough, Kenilworth, New Jersey, USA), $2.5 \mu \mathrm{g} / \mathrm{ml}$ of fungizone (Bristol-MyersSquibb, New York, USA), $0.25 \mathrm{ml}$ sodium bicarbonate solution (Merck, Darmstadt, Germany), $10 \mathrm{~mm}$ of HEPES (Sigma, St. Louis, Missouri, USA), and 10\% Fetal bovine serum (FBS) (Cultilab, Campinas, São Paulo, Brazil) and maintained at $37^{\circ} \mathrm{C}$ in an environment containing $5 \%$ of $\mathrm{CO}_{2}$.

\section{Evaluated alginates}

The sample was composed of three different alginate brands for orthodontic use, divided into three groups: JCO (Jeltrate Chromatic Ortho, Dentsply, Petrópolis, Brazil, Lot 955069), OP (Orthoprint, Zhermack, Rovigo, ltaly, Lot 72251) and CO (Cavex Orthotrace, Cavex, Nederland, Lot 080910).

\section{Composition of evaluated alginates (Provided by the manufacturer)}

Diatomite, potassium alginate, calcium sulfate, magnesium oxide, iron oxide, tetrasodium pyrophosphate, and spearmint oil.

\section{Test specimen fabrication}

To fabricate the test specimens, the material was manipulated for 1 minute using a rubber bowl and plastic spatula in accordance with the manufacturer's recommendations. After correct homogenization, the alginate was inserted in silicone rings measuring $4 \mathrm{~mm}$ in diameter and $4 \mathrm{~mm}$ height, until it was completely jellified.

\section{Controls}

To verify the cell response to the extreme conditions, another three groups were inserted: Group CC (cell control) in which the cells were not exposed to any material; Group C+ (positive control) consisting of a detergent Tween 80 (Polyoxyethelene-20-Sorbi$\tan$ ) at $10 \%$; Group C- (negative control), 100\% PBS Solution (Phosphate-buffered saline).

\section{Cytotoxicity test of the materials}

The materials were previously sterilized by exposure to UV light (Labconco, Kansas, Missouri, USA) for 1 hour., three samples of each material were then placed in 24-well plates containing culture medium (MEM) 
(Cultilab, Campinas, São Paulo, Brazil). After 2 minutes in contact with the culture medium, the supernatants were collected for posterior evaluation.

The supernatants were placed, in triplicate, in a 96-well plate containing a confluent monolayer of L929 cells and incubated for 24 hours at $37^{\circ} \mathrm{C}$ in an environment containing $5 \%$ of $\mathrm{CO}_{2}$. After incubation time, the effect on cell viability was determined by means of the dye-uptake technique, described by Neyndorff et $\mathrm{al}^{16}$ (1990). After 24 hours of incubation, $100 \mu \mathrm{l}$ of $0.01 \%$ neutral red (Sigma, St. Louis, Missouri, USA), was added to culture medium in each well of the miniplates, and these were incubated at $37^{\circ} \mathrm{C}$ for 3 hours for the dye to penetrate into the live cells. After this interval, and after dispensing the dye, $100 \mu \mathrm{l}$ of $4 \%$ formaldehyde solution (Reagen) was added to $\mathrm{PBS}\left(\mathrm{NaCl} 130 \mathrm{~mm} ; \mathrm{KCl} 2 \mathrm{~mm} ; \mathrm{Na}_{2} \mathrm{HPO}_{4}\right.$ $2 \mathrm{H}_{2} \mathrm{O} 6 \mathrm{~mm} ; \mathrm{K}_{2} \mathrm{HPO}_{4} 1 \mathrm{~mm}, \mathrm{pH}$ 7.2) for 5 minutes, to promote cell fixation to the plates. Next, in order to extract the dye, $100 \mu \mathrm{l}$ of $1 \%$ acetic acid solution (Vetec, Rio de Janeiro, Brazil) with 50\% methanol was added (Reagen, Rio de Janeiro, Brazil). After 20 minutes the readout was taken in a spectrophotometer (BioTek, Winooski, Vermont, USA) at a wavelength of $492 \mathrm{~nm}$.

\section{Statistical analysis}

Statistical analyses were performed with the program SPSS 13.0 (SPSS Inc., Chicago, Illinois, USA). Descriptive statistical analysis including mean and standard deviation were calculated for the groups evaluated. The values for the quantity of viable cells were submitted to the analysis of variance (ANOVA) to determine whether there was statistical difference among the groups, and afterwards the Tukey test was performed.

\section{RESULTS}

The results demonstrated statistical differences between Group $\mathrm{C}+$ and all the others, and between Groups $\mathrm{C}$ - and $\mathrm{CC}$ and the experimental Groups JCO, OP and CO ( $<<0.05)$. No statistical significance was observed between Group JCO, OP and CO, and between Groups $\mathrm{C}$ - and CC ( $\mathrm{p}>0.05)$ (Table 1).

With regard to cell viability Group $\mathrm{C}+$ presented the lowest cell viability followed by experimental groups CO, OP and JCO (Fig 1).
Table 1 - Mean, standard deviation, percentage of viable cells and statistical analysis of the groups evaluated.

\begin{tabular}{cccc}
\hline Groups & M. Cell / S.D. & \% Viable Cells & Stat. \\
\hline JCO & $644.25 \pm 193.59$ & 50.6 & $\mathrm{~A}$ \\
OP & $617 \pm 173.86$ & 48.46 & $\mathrm{~A}$ \\
CO & $560.87 \pm 23.60$ & 44.05 & $\mathrm{~A}$ \\
C+ & $67 \pm 2.20$ & 5.26 & $\mathrm{~B}$ \\
C- & $1111.5 \pm 67.85$ & 87.31 & $\mathrm{C}$ \\
CC & $1273.75 \pm 125.71$ & 100 & $\mathrm{C}$ \\
\hline
\end{tabular}

M. Cell: Mean values of quantity of viable cells;

SD: Standard Deviation:

Stat: Statistics: In which equal letters represent absence of statistical differences.

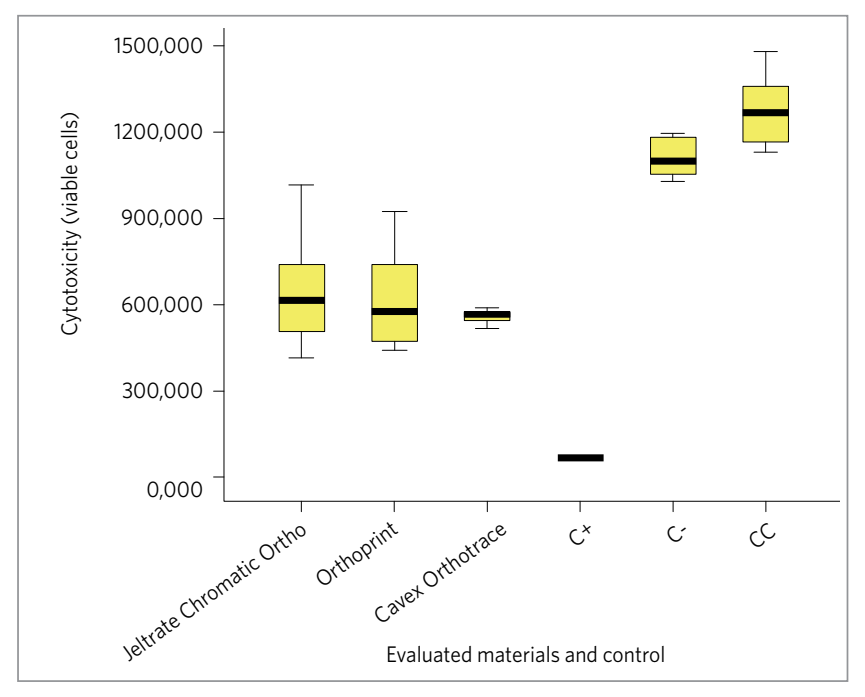

Figure 1 - Diagram showing the values of cellular viability between evaluated groups.

\section{DISCUSSION}

Alginate is the most accepted and used impression material in Orthodontics. Manufacturers produce orthodontic alginate powder containing various components with different purposes. Many substances such as zinc, barium, cadmium, lead silicates and fluorides have been added to some commercial brands with the aim of improving the physical, chemical and mechanical properties, causing concern with regard to the toxicity of these materials. ${ }^{6}$

According to Syndiskis et al, ${ }^{24}$ alginate is capable of affecting the ability of cells reproduction. The substance may not be sufficiently toxic to kill the cells, but is toxic enough to inhibit cell growth, or on a small scale, affect normal cell function. In this context, while a single contact may not cause clinical symptoms, repeated contacts with the material alter or affect cell viability, and may result in a late toxic or allergic reaction. 
Thus, the aim of the present study was to evaluate the cytotoxicity of three alginate brands for orthodontic use, in a cell culture experiment.

The cell cultures have been used as part of a series of tests recommended for evaluating the biologic behavior of materials to be placed in contact with human tissues. ${ }^{9,14,21}$ In this study, cytotoxicity tests were performed to evaluate the cytotoxicity of alginates. The L929 cell lineage (mouse fibroblasts) was used because these cells are frequently used in various studies in which the intention was to evaluate the cytotoxicity of materials for dental use. . $^{1,8,10,13}$

The neutral red assay method was used to evaluate cell viability. The analysis procedure with neutral red is a cell survival/viability assay, based on the capacity of viable cells to incorporate and process the neutral red within the lysosomes. Normally, it is performed in adherent cells. Neutral red is a weak cationic dye that promptly penetrates into the cell membrane and accumulates intracellularly in the lysosomes (lysosomal $\mathrm{pH}<$ cytoplasmic $\mathrm{pH}$ ), combining with the anionic part of the lysosomal matrix. ${ }^{12}$ The changes in cell surface or sensitive lysosomal membrane led to lysosomal weakness and other changes that gradually become irreversible. These alterations that occur by the action of xenobiotics result in the reduction in absorption and combination of neutral red. Thus, it is possible to distinguish viable, damaged or dead cells, which is the basis of the test. The quantity of dye incorporated into the cells is measured by spectrometry, and is directly proportional to the number of cells with intact membranes.

This method was introduced to evaluate the cytotoxicity of materials for orthodontic use by Pithon et al, ${ }^{17}$ comparing with the agar diffusion method. In the mentioned study, both methods were shown to be apt for the evaluation of cytotoxicity.

The results of the present study demonstrated the cytotoxicity of the three studied brands of alginates, as follows: Jeltrate ( $50.6 \%$ cell viability) followed by Orthoprint (48.46\%) and Cavex Orthotrace (44.05\%). Statistical differences were found among the experimental groups and the cell control (CC) and negative control (C-). No statistical differences were observed among the experimental groups evaluated. This result may be justified with the similar constitution of these materials.
The evaluation time interval was 2 minutes, because this is the interval that usually alginate stays in contact with the oral mucosa during the impression taking as recommended by the manufacturer. The test specimens remained in contact with the culture medium for this period. After this, the supernatant was collected from the culture medium, and was then placed in contact with the cells. The test specimens were not placed in direct contact with the cells, since the mechanical contact of these with the cells may harm them, as suggested by Costa. ${ }^{5}$

In order to evaluate the cell response to extreme situations, a positive control group $(\mathrm{C}+)$ was inserted in the study, the purpose was to generate lesions to the cells. The material used as positive control was $10 \%$ Tween, which is a non ionic surfactant, toxic to biologic membranes, ${ }^{18}$ composed of polyoxyethylene derivatives of sorbitan fatty acid esters, with the characteristics of stimulating the secretion of proteins in microorganism, ${ }^{23}$ in addition to altering the morphology and surface of the cell wall. ${ }^{7}$ As expected, the positive control presented high toxicity, differing statistically from all the other groups $(\mathrm{p}<0.05)$.

The negative control group, consisted of a $100 \%$ PBS solution (Phosphate-buffered saline), recognized as non toxic to cells. The aim of this control was to evaluate only the physical action on cells. This procedure demonstrated low cytotoxicity, with absence of statistical significance from the cell control group, in which no substance was placed in contact with the cells.

Based on the present results it should be considered that success in the orthodontic clinic involves not only mastering the corrective technique to achieve an ideal dental occlusion, but also requires the application of biosafety rules and concern about the local and systemic consequences of the dental materials used for this purpose. The evaluation with regard to the possible cytotoxic effects must be verified in order to obtain safety with respect to the use of a certain material.

\section{CONCLUSION}

By conducting this study, it could be concluded that all the alginate brands evaluated demonstrated cell cytotoxicity and presented no statistical differences among them. 


\section{REFERENCES}

1. Alcaide M, Serrano MC, Pagani R, Sánchez-Salcedo S, Nieto A, Vallet-Regí M, et al. L929 fibroblast and Saos-2 osteoblast response to hydroxyapatite-betaTCP/ agarose biomaterial. J Biomed Mater Res A. 2009;89(2):539-49.

2. Braga SRS, Braga AS, Catirse ABCEB, Vaz LG, Spadaro ACC. Potencial tóxico dos alginatos para uso odontológico. Rev Ciênc Farm Básica Apl. 2007;28(2):153-8.

3. Braga AS, Catirse ABCEB, Vaz LG, Spadaro ACC. Quantitative analysis of potentially toxic metals in alginates for dental use. Rev Ciênc Farm Básica Apl. 2005;26(2):125-30.

4. Camargo EL, Mucha JN. Moldagem e modelagem em Ortodontia. Rev Dental Press Ortod Ortop Facial. 1999;4(3):37-50

5. Costa CA, Edwards CA, Hanks CT. Cytotoxic effects of cleansing solutions recommended for chemical lavage of pulp exposures. Am J Dent. 2001;14(1):25-30.

6. De Freitas JF. Potential toxicants in alginate powders. Aust Dent J. 1980;25(4):224-8

7. Domingues FC, Queiroz JA, Cabral JM, Fonseca LP. The influence of culture conditions on mycelial structure and cellulase production by Trichoderma reesei Rut C-30. Enzyme Microb Technol. 2000;26(5-6):394-401.

8. Donadio M, Jiang J, Safavi KE, Zhu Q. Cytotoxicity evaluation of Activ GP and Resilon cones in vitro. Oral Surg Oral Med Oral Pathol Oral Radiol Endod. 2008;106(1):e76-9.

9. Estrela C. Metodologia científica: ensino e pesquisa em Odontologia. São Paulo: Artes Médicas; 2005. 15 p.

10. Feizzadeh B, Afshari JT, Rakhshandeh H, Rahimi A, Brook A, Doosti H. Cytotoxic effect of saffron stigma aqueous extract on human transitional cell carcinoma and mouse fibroblast. Urol J. 2008;5(3):161-7.

11. Freitas JF. Potential toxicants in alginate powders. Aust Dent J. 1980;25(4):224-8.

12. Griffon G, Marchal C, Merlin JL, Marchal S, Parache RM, Bey P. Radiosensitivity of multicellular tumour spheroids obtained from human ovarian cancers. Eur J Cancer. 1995;31A(1):85-91.
13. Jin $\mathrm{CY}$, Zhu BS, Wang XF, Lu QH. Cytotoxicity of titanium dioxide nanoparticles in mouse fibroblast cells. Chem Res Toxicol. 2008;21(9):1871-7. Epub 2008 Aug 5.

14. Jorge JH, Giampaolo ET, Pavarina AC. Cytotoxicity of the dental materials. A literature review. Rev Odontol UNESP. 2004;33(2):65-8.

15. Monti E. Tratado de Ortodoncia. Buenos Aires: El Ateneo; 1953.

16. Neyndorff HC, Bartel DL, Tufaro F, Levy JG. Development of a model to demonstrate photosensitizer-mediated viral inactivation in blood. Transfusion. 1990;30(6):485-90

17. Pithon Mm, Santos RL, Ruellas ACO, Fidalgo TKS, Romanos MTV, Mendes GV. Citotoxicidade in vitro de elásticos ortodônticos: comparação entre duas metodologias. Rev Saúde Com. 2008;4(1):19-26.

18. Rege BD, Kao JP, Polli JE. Effects of nonionic surfactants on membrane transporters in Caco-2 cell monolayers. Eur J Pharm Sci. 2002;16(4-5):237-46.

19. Romano FL, Pereira Neto JS, Magnani MBBA, Nouer DF, Siqueira VCV. Moldagem ortodôntica. Rev Clín Ortod Dental Press. 2005;4(1):15-22.

20. Samuel SW, Miranda LA, Dutra CAV. Potencial tóxico dos alginatos. Rev Fac Odontol Porto Alegre. 1995;36(2):14-6

21. Santos RL, Pithon Mm, Oliveira MV, Mendes GS, Romanos MTV, Ruellas ACO Cytotoxicity of intraoral orthodontic elastics. Braz J Oral Sci. 2008;7(24):1520-5.

22. Strang RHW. Tratado de Ortodoncia. Rio de Janeiro: Editorial Bibliográfica; 1957.

23. Stutzenberger FJ. Interference of the detergent Tween 80 in protein assays. Anal Biochem. 1992;207(2):249-54.

24. Sydiskis RJ, Gerhardt DE. Cytotoxicity of impression materials. J Prosthet Dent. 1993:69(4):431-5 